\title{
Gambaran Histopatologi Pankreas Tikus Putih (Rattus norvegicus) Pasca Perlakuan Iskemia-Reperfusi Ginjal
}

\author{
Elva Rosiana $^{1 *}$, Wiwit Ade Fidiawati ${ }^{2}$, Darmawi $^{3}$
}

\begin{abstract}
Ischemic-reperfusion injury is defined by a condition of hypoperfusion in the spesific organ followed by reperfusion (reoxygenation) inducing tissue damage. Tissue damage produces reactive oxygen species (ROS) leading to oxidative stress condition. Oxidative stress mediate the lipid peroxidation reactions, harm the cell and finally facilitate the cell death. The aim of this study was to evaluate the histopathologic feature of white rat's pancreas post renal ischemiareperfusion. This study was an experimental laboratory research with post-test-only control group design including 20 male white rats. Rats were divided into 5 groups, control, treatment 1 (45 minutes ischemia), treatment 2 (45 minutes ischemia followed by 1 hour reperfusion), treatment 3 (45 minutes ischemia followed by 2 hours reperfusion) and treatment 4 (45 minutes ischemia followed by24 hours reperfusion). We found the change of the histopathological characteristics of white rat's pancreas in term of edema, leukocyte infiltration and vacuolization.
\end{abstract}

Keywords: renal ischemia-reperfusion, pancreas, histopathology, reactive oxygen species (ROS).

Cedera iskemia-reperfusi merupakan kondisi hipoperfusi pada organ yang diikuti dengan reperfusi (reoksigenasi). Efek yang ditimbulkan dari cedera iskemia-reperfusi adalah kerusakan jaringan. ${ }^{1}$ Selama cedera iskemia-reperfusi jaringan yang rusak menghasilkan jumlah reactive oxygen species (ROS) yang berlebihan. ROS yang berlebih menyebabkan terjadinya stres oksidatif yang dapat mengubah fosforilasi oksidatif di mitokondria, penurunan ATP, peningkatan kalsium intraseluler dan aktivasi dari membran fosfolipid protease. ${ }^{2}$

Aliran darah selama fase reperfusi pada cedera iskemia-reperfusi dapat menghasilkan oksigen radikal bebas yang mengarah kepada peroksidasi lipid sebagai jalur utama cedera jaringan akibat radikal bebas. Pembentukan radikal bebas meningkatkan cedera jaringan ginjal melalui peroksidasi lipid membran dan kerusakan dari protein dan DNA yang berperan dalam apoptosis dan kematian sel. Hal ini juga tidak terlepas dari enzim antioksidan seperti katalase, superoksida dismutase

\footnotetext{
* Korespondensi penulis : elvarosiana24@gmail.com

${ }^{1}$ Fakultas Kedokteran Universitas Riau.

${ }^{2}$ KJF Patologi Anatomi Fakultas Kedokteran Universitas Riau

${ }^{3}$ KJF Histologi Fakultas KedokteranUniversitas Riau
}

dan gluthatione peroksidase yang bertanggung jawab dalam terjadinya cedera iskemia-reperfusi. ${ }^{3}$

ROS yang dihasilkan pada cedera iskemiareperfusi selain menyebabkan kerusakan pada jaringan lokal, juga mempengaruhi organ yang berada jauh dari lokasi awal terjadinya cedera iskemiareperfusi, salah satunya adalah pankreas. ROS dianggap sebagai penyebab penting kematian sel pankreas. ${ }^{4}$ Selain menyebabkan cedera sel secara langsung, ROS juga meningkatkan aktivasi leukosit, kemotaksis dan leukosit-endotelial setelah iskemiareperfusi. Iskemia-reperfusi menyebabkan aktivasi komplemen dan pembentukan beberapa mediator proinflamasi yang mengubah homeostasis vaskular yang berperan dalam terjadinya cedera pada remote organ. ${ }^{5}$

Peristiwa kunci terjadinya adalah aktivasi dari polimorfonuclear (PMN) dalam vaskular setelah iskemia, diikuti dengan perekrutan PMN yang diaktifkan ke jaringan remote. Hal ini tidak hanya melibatkan aktivasi PMN, tetapi juga aktivasi sel endotel pada jaringan yang jauh. Hal tersebut ditandai dengan adanya peningkatan ekspresi permukaan molekul adesi endotelial. Pelepasan sistem mediator inflamasi dari jaringan yang 
mengalami cedera awal mempengaruhi peningkatan monosit dan neutrofil. Peningkatan monosit dan neutrofil menyebabkan terjadinya aktivasi sistemik, sehingga terjadi peningkatan PMN ke tempat yang jauh dari lokasi awal iskemia-reperfusi. ${ }^{6}$

Dampak yang ditimbulkan cedera iskemiareperfusi ginjal adalah terjadi penurunan fungsi dan struktur pankreas yang signifikan sebagai indikator pankreatitis akut. ${ }^{7}$ Melihat dampak yang ditimbulkan oleh cedera iskemia-reperfusi ginjal terhadap pankreas, maka peneliti tertarik untuk meneliti pankreas tikus putih (Rattus norvegicus) yang akan dinilai dengan memperhatikan gambaran histopatologinya.

\section{METODE}

Penelitian ini adalah penelitian eksperimental laboratorik dengan desain post test-only control group yang bertujuan untuk mengetahui gambaran histopatologi pankreas tikus putih pasca perlakuan iskemia-reperfusi ginjal. Penelitian ini dilaksanakan di rumah hewan Fakultas Kedokteran Universitas Riau pada bulan Juli 2018 - Januari 2019. Kriteria hewan coba yang digunakan pada penelitian ini adalah tikus putih galur wistar, berjenis kelamin jantan, berumur 2-3 bulan dengan berat rata-rata 150200 gr/ekor, dinyatakan sehat dilihat dari rambut tidak kusam, rontok atau botak serta bergerak aktif. Jumlah sampel yang digunakan pada penelitian ini adalah 20 ekor tikus yang didapat dari perhitungan dengan menggunakan rumus Resource Equation Method $(\mathrm{E}=\mathrm{N}-\mathrm{t})$.

Hewan coba dibagi dalam 5 kelompok secara acak, setiap kelompok terdiri dari 4 ekor tikus. Kelima kelompok perlakuan ini adalah kelompok kontrol, kelompok perlakuan 1 (iskemia 45 menit), kelompok perlakuan 2 (iskemia 45 menit diikuti reperfusi 1 jam), kelompok perlakuan 3 (iskemia 45 menit diikuti reperfusi 2 jam) dan kelompok perlakuan 4 (iskemia 45 menit diikuti reperfusi 24 jam).

Tikus yang akan dilakukan percobaan iskemiareperfusi ginjal dianestesi secara intramuskular menggunakan Ket A Xyl dengan dosis 0,1/
KgBB.Dibawah pengaruh anestesi, tikus diposisikan pada posisi telungkup (prone position), dilanjutkan dengan pembedahan untuk mencari arteri renalis. Setelah arteri renalis ditemukan, dilanjutkan dengan pembuatan percobaan iskemia dengan cara mengklem arteri renalis tikus putih. Selanjutnya, bagi kelompok yang akan dilakukan percobaan reperfusi, klem dibuka dari arteri renalis yang dilakukan pengkleman sebelumnya.

Setelah percobaan iskemia-reperfusi ginjal selesai, dilanjutkan dengan pembedahan pada regio abdomen tikus untuk diambil organ pankreasnya. Organ pankreas yang telah diambil, dimasukkan ke dalam buffer formalin 10\% selama 24-48 jam dan dibawa ke Laboratorium Patologi Anatomi Swasta di Pekanbaru untuk dibuat preparat mikroskopisnya.

Penilaian gambaran histopatologi dilakukan dengan menggunakan mikroskop perbesaran 400 kali pada 10 lapangan pandang. Perubahan gambaran histopatologi pankreas tikus putih yang dinilai adalah edema dan infiltrasi leukosit perivaskular. Penilaian dilakukan dengan menggunakan sistem scoring.

\section{HASIL}

Penilaian gambaran histopatologi pankreas tikus putih pada kelima kelompok dilakukan di bawah mikroskop yang dinilai pada 10 lapangan pandang. Perubahan gambaran histopatologi pankreas tikus putih yang dinilai adalah edema dan infiltrasi leukosit perivaskular. Penilaian dilakukan dengan menggunakan sistem scoring.

\section{Gambaran Edema pada Pankreas Tikus Putih}

Penilaian gambaran histopatologi yang dilakukan pada kelima kelompok perlakuan berupa edema pada pankreas tikus putih dinilai menggunakan scoring, dengan skor yang digunakan adalah 0-3. Dimana, skor 0 menunjukkan bahwa tidak terdapat edema, 1 edema ringan, 2 edema sedang dan 3 edema berat. Hasil penilaian dapat dilihat pada tabel 1 . 
Tabel 1. Hasil Penilaian Edema pada Pankreas Tikus Putih

\begin{tabular}{cccc}
\hline Kelompok & Skor & $\begin{array}{c}\text { Frekuensi } \\
\text { (ekor) }\end{array}$ & $\begin{array}{c}\text { Persentase } \\
(\mathbf{\%})\end{array}$ \\
\hline Kontrol & 0 & 4 & 100 \\
& 1 & 0 & 0 \\
& 2 & 0 & 0 \\
& 3 & 0 & 0 \\
\hline Perlakuan 1 & 0 & 0 & 0 \\
& 1 & 4 & 100 \\
& 2 & 0 & 0 \\
\hline Perlakuan 2 & 3 & 0 & 0 \\
& 0 & 4 & 0 \\
& 1 & 0 & 0 \\
\hline Perlakuan 3 & 2 & 0 & 0 \\
& 3 & 0 & 0 \\
& 0 & 4 & 0 \\
\hline Perlakuan 4 & 1 & 0 & 0 \\
& 2 & 0 & 0 \\
& 3 & 0 & 00 \\
\hline
\end{tabular}

Berdasarkan tabel 1, pada kelompok kontrol, yaitu kelompok yang tidak diberi perlakuan iskemia maupun iskemia-reperfusi tidak ditemukan adanya perubahan gambaran histopatologi berupa edema. Selanjutnya, pada kelompok perlakuan 1 (iskemia 45 menit), perlakuan 2 (iskemia 45 menit diikuti reperfusi 1 jam) dan kelompok perlakuan 3 (iskemia 45 menit diikuti reperfusi 2 jam) pada seluruh sampel $(100 \%)$ di masing- masing kelompok perlakuan tersebut ditemukan gambaran histopatologi berupa edema ringan (skor 1). Selanjutnya, pada kelompok perlakuan 4, yaitu kelompok yang diberi perlakuan iskemia 45 menit diikuti reperfusi 24 jam ditemukan adanya peningkatan edema, dimana dari tiga kelompok perlakuan sebelumnya hanya ditemukan edema ringan pada kelompok perlakuan ini edema yang ditemukan adalah edema sedang (skor 2) pada seluruh sampel $(100 \%)$.

\section{Gambaran Infiltrasi Leukosit pada Pankreas Tikus Putih}

Penilaian gambaran histopatologi berupa infiltrasi leukosit pada pankreas tikus putih ini sama halnya dengan penilaian edema, yaitu sama-sama menggunakan scoring,. Skor yang digunakan adalah 0-3, dengan skor 0 (tidak terdapat infiltrasi leukosit), 1 (infiltrasi leukosit ringan), 2 (infiltrasi leukosit sedang) dan 3 (infiltrasi leukosit padat). Hasil penilaian infiltrasi leukosit yang dilakukan pada kelima kelompok perlakuan dapat dilihat pada tabel 2. 
Tabel 2. Hasil Penilaian Infiltrasi Leukosit pada Pankreas Tikus Putih

\begin{tabular}{cccc}
\hline Kelompok & Skor & $\begin{array}{c}\text { Frekuensi } \\
\text { (ekor) }\end{array}$ & $\begin{array}{c}\text { Persentase } \\
(\%)\end{array}$ \\
\hline Kontrol & 0 & 4 & 100 \\
& 1 & 0 & 0 \\
& 2 & 0 & 0 \\
& 3 & 0 & 0 \\
\hline Perlakuan 1 & 0 & 4 & 100 \\
& 1 & 0 & 0 \\
& 2 & 0 & 0 \\
Perlakuan 2 & 3 & 0 & 0 \\
& 0 & 0 & 0 \\
& 1 & 4 & 0 \\
& 2 & 0 & 0 \\
\hline Perlakuan 3 & 3 & 0 & 100 \\
& 0 & 0 & 0 \\
& 1 & 4 & 0 \\
\hline Perlakuan 4 & 2 & 0 & 0 \\
& 3 & 0 & 0 \\
& 0 & 0 & 100 \\
& 1 & 0 & 0 \\
\hline
\end{tabular}

Berdasarkan tabel 2, pada kelompok kontrol dan kelompok perlakuan 1 (iskemia 45 menit) tidak ditemukan adanya perubahan gambaran histopatologi berupa infiltrasi leukosit. Pada kelompok perlakuan 2 (iskemia 45 menit diikuti reperfusi 1 jam) dan perlakuan 3 (iskemia 45 menit diikuti reperfusi 2 jam) ditemukan adanya gambaran histopatologi berupa infiltrasi leukosit ringan (skor 1) pada seluruh sampel di masing- masing kelompok perlakuan $(100 \%)$. Selanjutnya, pada kelompok perlakuan 4 (iskemia 45 menit diikuti reperfusi 24 jam) ditemukan adanya peningkatan infiltrasi leukosit yang ditemukan, dimana pada kelompok perlakuan sebelumnya infiltrasi hanya ditemukan infiltrasi leukosit ringan pada kelompok ini infiltrasi leukosit yang ditemukan adalah infiltrasi leukosit sedang (skor 2) pada seluruh sampel.

\section{Gambaran Histopatologi Lain pada Pankreas Tikus Putih}

Pada penelitian ini selain ditemukan adanya perubahan gambaran histopatologi pankreas tikus putih berupa edema dan infiltrasi leukosit juga ditemukan gambaran histopatologi berupa vakuolisasi. Pada kelompok kontrol tidak ditemukan adanya vakuolisasi. Pada kelompok perlakuan 1 (iskemia 45 menit), kelompok perlakuan 2 (iskemia 45 menit diikuti reperfusi 1 jam) dan kelompok perlakuan 3 (iskemia 45 menit diikuti reperfusi 2 jam) ditemukan adanya gambaran histopatologi berupa vakuolisasi ringan. Pada kelompok perlakuan 4, yaitu kelompok yang diberi perlakuan iskemia 45 menit diikuti reperfusi 24 jam ditemukan adanya peningkatan vakuolisasi, dimana pada kelompok perlakuan sebelumnya vakuolisasi yang ditemukan hanya vakuolisasi ringan, namun pada kelompok perlakuan ini ditemukan vakuolisasi sedang. Selanjutnya, mengenai perubahan gambaran histopatologi berupa edema, infiltrasi leukosit dan vakuolisasi pada pankreas tikus putih dapat dilihat pada gambar $1-6$. 

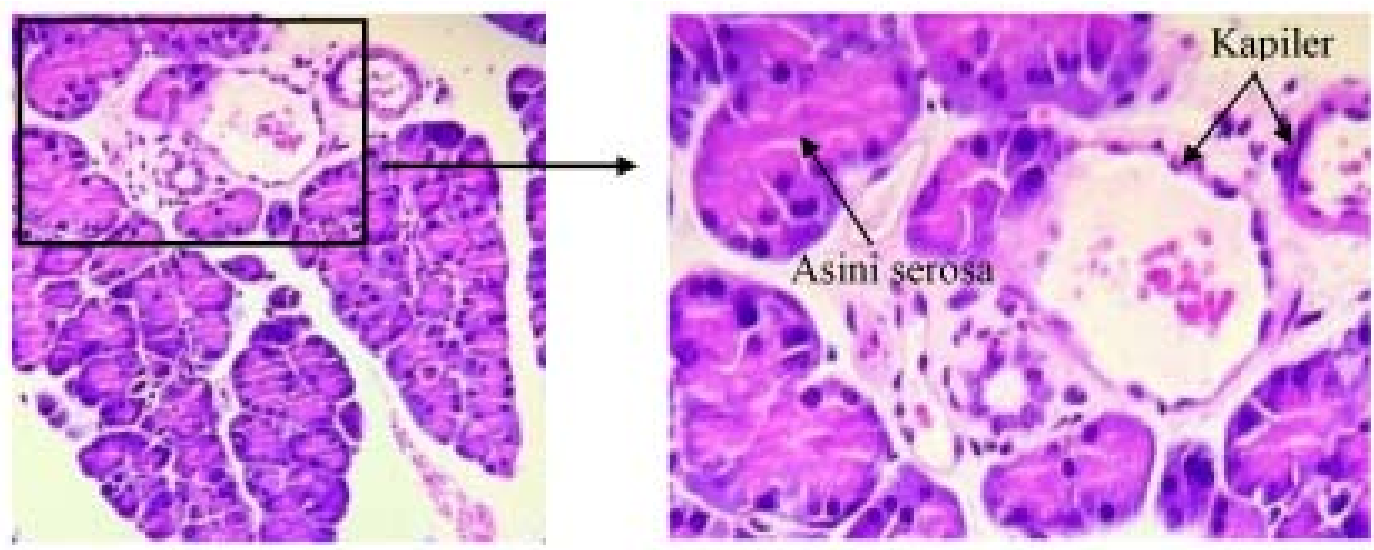

Gambar 1 Gambaran histopatologi pankreas normal. Pewarnaan H\&E. 400x.
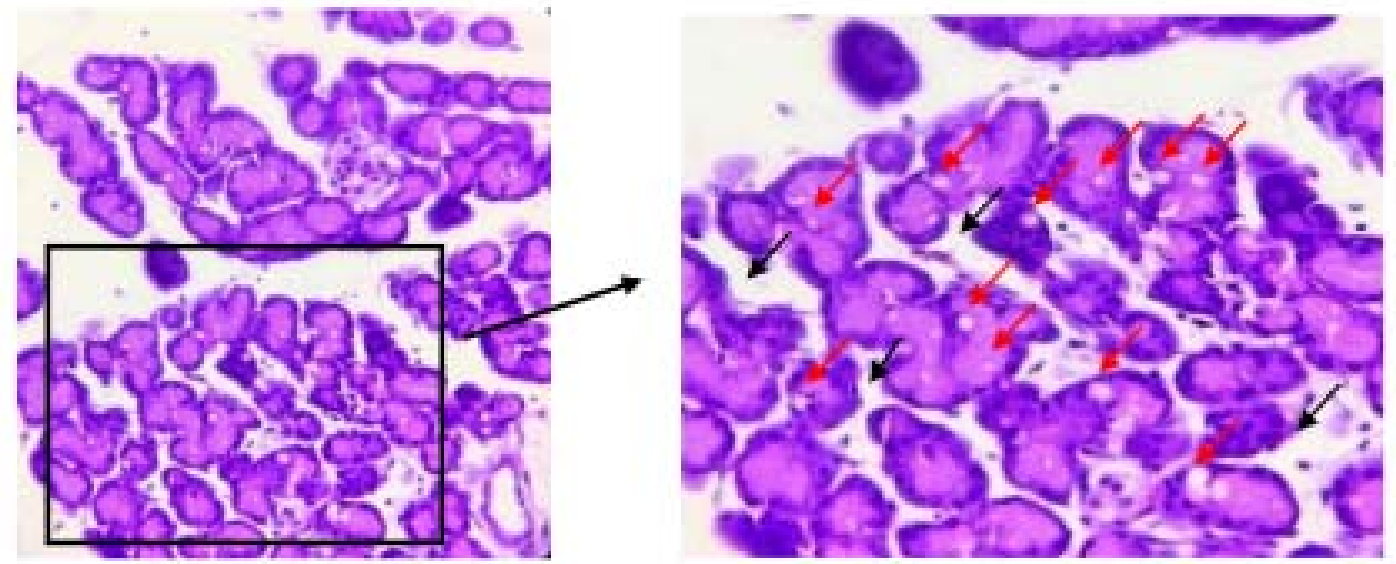

Gambar2 Gambaran histopatologi pankreas berupa edema intersisial ringan yang terdapat diantara asini serosa (panah hitam) dan vakuolisasi ringan (panah merah). Pewarnaan H\&E. 400x.
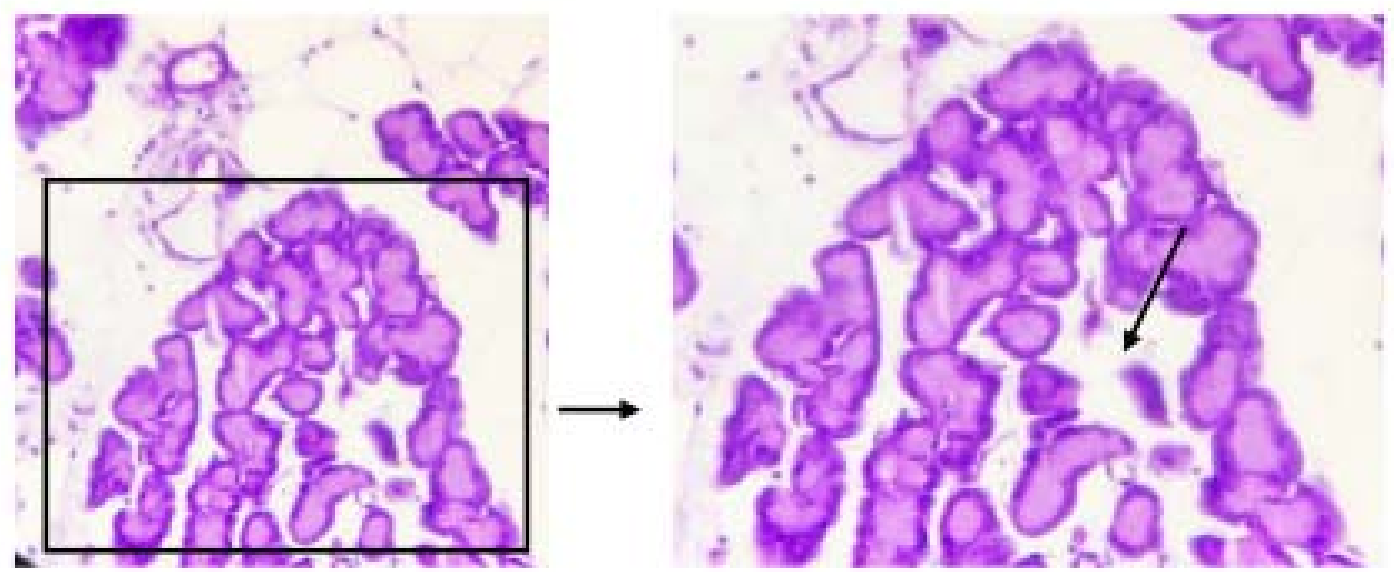

Gambar3 Gambaran histopatologi pankreas berupa edema intersisial sedang yang terdapat diantara asini serosa (panah hitam). Pewarnaan H\&E. 400x. 

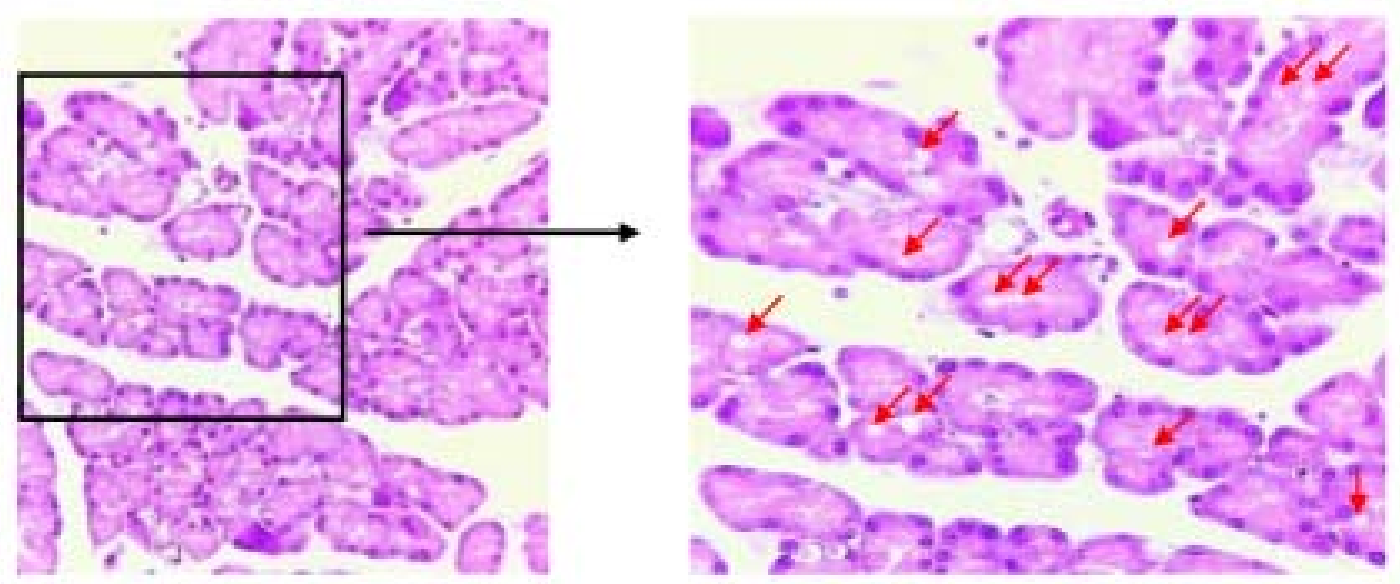

Gambar 4 Gambaran histopatologi pankreas berupa vakuolisasi sedang (panah merah). Pewarnaan H\&E. 400x.
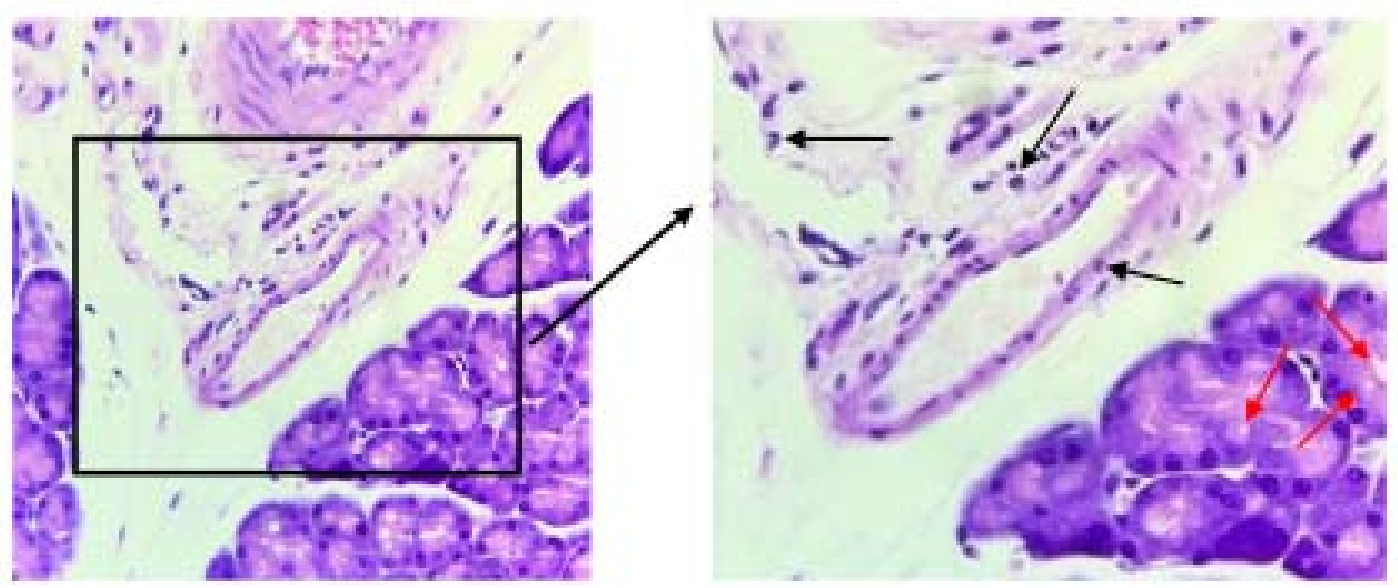

Gambar 5 Gambaran histopatologi pankreas berupa vakuolisasi ringan (panah merah) dan infiltrasi leukosit ringan (panah hitam). Pewarnaan H\&E. 400x.
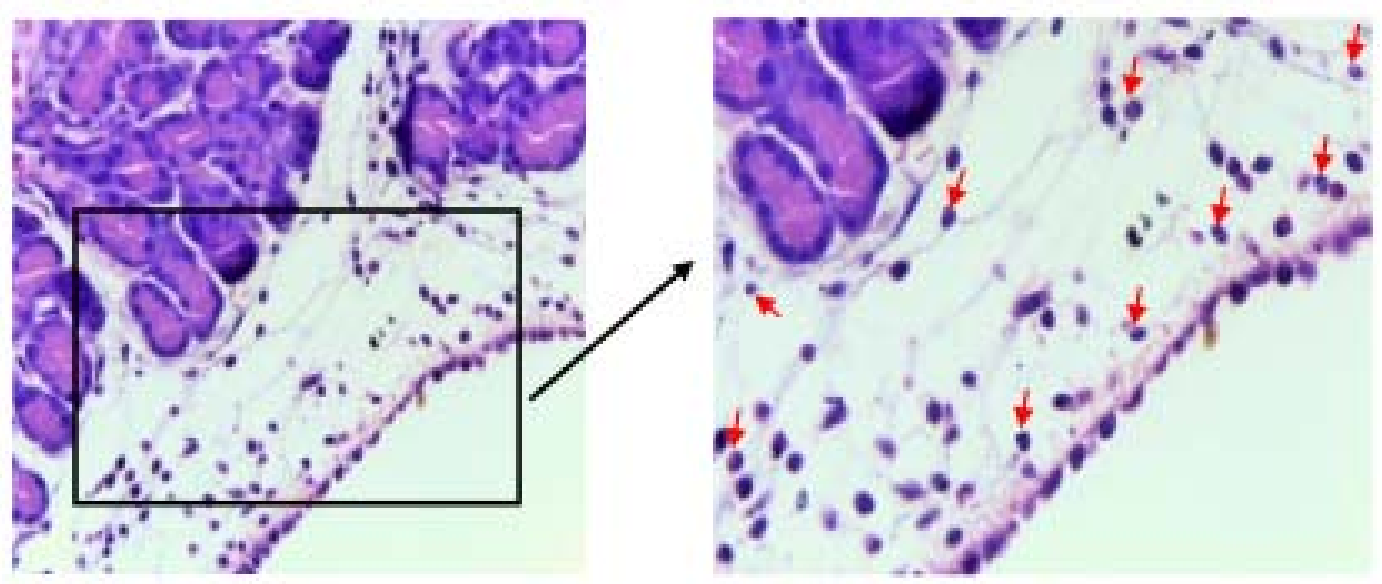

Gambar6 Gambaran histopatologi pankreas berupa infiltrasi leukosit sedang (panah merah). Pewarnaan H\&E. 400x. 


\section{PEMBAHASAN}

\section{Gambaran Edema pada Pankreas Tikus Putih}

Hasil penelitian berdasarkan skoring, didapatkan adanya gambaran histopatologi berupa edema yang ditemukan pada seluruh kelompok perlakuan. Namun, edema yang ditemukan pada kelompok perlakuan 1 tidak terlalu signifikan dikarenakan edema hanya ditemukan pada satu lapangan pandang. Edema terjadi akibat adanya produksi TNF-á dan menyebabkan inflamasi. Hal ini menyebabkan terjadinya gangguan pada pompa ion, terutama pompa $\mathrm{Na}^{+} / \mathrm{K}^{+}$ATPase. Gangguan pada pompa $\mathrm{Na}^{+} / \mathrm{K}^{+}$ATPase mengakibatkan ion $\mathrm{Na}^{+}$ tidak dapat di pompa keluar sel, sehingga konsentrasi ion $\mathrm{Na}^{+}$di intrasel menjadi tinggi. ${ }^{6}$

Selanjutnya, edema yang ditemukan pada kelompok perlakuan 2, 3 dan 4 mengalami peningkatan dibandingkan dengan kelompok perlakuan 1. Hal ini dihubungkan dengan dilakukannya reperfusi pada ketiga kelompok perlakuan tersebut. Pada saat reperfusi ROS yang dihasilkan mengalami peningkatan dibandingkan pada saat iskemia. Dari penelitian yang dilakukan oleh Galindo dkk mengenai ROS menginduksi terjadinya pembengkakan sel, menerangkan bahwa peningkatan ROS menyebabkan masuknya kalsium ekstrasel dengan melintasi membran plasma, diikuti dengan pelepasan kalsium dari intrasel di mitokondria yang menyebabkan pembengkakan pada mitokondria. ${ }^{8}$

Penemuan gambaran edema pada penelitian ini sejalan dengan penelitian yang dilakukan oleh Hussein dkk yang meneliti tentang cedera sekunder pankreas pada iskemia-reperfusi ginjal dengan mengklem kedua arteri renalis selama 45 menit pada tikus. Dalam penelitiannya edema yang ditemukan pada 2 jam setelah iskemia mengalami peningkatan di hari ke $7 .{ }^{4}$ Hal yang sama juga ditemukan pada penelitian yang dilakukan Chrysikos dkk yang meneliti tentang administrasi lazaroid U-74389G pada cedera iskemia-reperfusi pankreas pada babi, yang melakukan iskemia dengan cara mengklem arteri mesenterika selama 30 menit dan diikuti reperfusi selama 30, 60, 90 dan 120 menit. Pada penelitiannya edema yang ditemukan pada menit ke 30 terus mengalami peningkatan hingga menit ke $120 .{ }^{9}$

\section{Gambaran Infiltrasi Leukosit pada Pankreas Tikus Putih}

Peningkatan gambaran histopatologi pankreas tikus putih jantan berupa infiltrasi leukosit perivaskular yang ditemukan pada kelompok perlakuan 2, 3 dan 4 juga dikaitkan dengan adanya peningkatan ROS pada saat reperfusi. Hal ini dijelaskan oleh Malek dkk pada penelitiannya mengenai patofisiologi iskemia-reperfusi. Dalam penelitiannya Malek dkk menjelaskan bahwa selain adanya aktivasi dari mediator inflamasi, ROS yang terbentuk pada waktu reperfusi juga berperan dalam menarik leukosit dan infiltrasi neutrofil ke dalam jaringan, sehingga terdapat peningkatan leukosit pada tempat tersebut. ${ }^{3}$ Dengan kata lain adanya peningkatan leukosit dipengaruhi oleh waktu reperfusi. Waktu reperfusi yang lama tentunya akan meningkatkan pembentukan ROS mengarah kepada peningkatan leukosit. Oleh karena itu infiltrasi leukosit bertambah banyak pada kelompok perlakuan 4 yang dilakukan reperfusi selama 24 jam.

Gambaran infiltrasi leukosit yang ditemukan pada penelitian ini sejalan dengan penelitian yang dilakukan oleh Abogresha dkk mengenai efek jarak jauh dari cedera iskemia-reperfusi ginjal pada pankreas. Dalam penelitiannya, iskemia ginjal dilakukan pada kedua arteri renalis selama 45 menit yang kemudian dilakukan reperfusi selama 1,3 dan 7 hari. ${ }^{8}$ Pada penelitiannya didapatkan adanya peningkatan infiltrasi leukosit perivaskular mulai dari hari pertama, ketiga sampai ketujuh. Hal yang sama juga ditemukan pada penelitian yang dilakukan Warzecha dkk yang meneliti tentang ekspresi imunohistokimia FGF-2, PDGF-A, VEGF dan TGFb RII di pankreas pada iskemia-reperfusi yang menginduksi pankreatitis akut. Pada penelitiannya iskemia dilakukan pada tikus dengan cara mengklem arteri splenika selama 30 menit diikuti reperfusi selama 1 jam, 5 jam, 12 jam, 1 hari dan 2 hari. Hasilnya menunjukkan bahwa terjadi peningkatan infiltrasi leukosit dari 1 jam sampai 2 hari setelah dilakukannya reperfusi. ${ }^{10}$

\section{Gambaran Vakuolisasi pada Pankreas Tikus Putih}

Pada penelitian ini selain ditemukan gambaran histopatologi berupa edema dan infiltrasi leukosit 
perivaskular juga ditemukan gambaran vakuolisasi sitoplasma pada sel asinar. Dari penelitian yang dilakukan oleh Amiralevi dkk mengenai efek paparan formaldehid oral akut pada histologi hati tikus wistar jantan menjelaskan bahwa vakuolisasi terjadi akibat adanya kegagalan pompa ion yang ada di membran plasma yang akan menyebabkan gangguan pada keseimbangan cairan dan ion didalam sel, sehingga terjadi pembengkakan sel dan timbulnya vakuolavakuola kecil disitoplasma. ${ }^{11}$

Penemuan vakuolisasi pada penelitian ini sejalan dengan penelitian yang dilakukan oleh Warzecha dkk yang meneliti tentang prekondisi iskemia pada kaki belakang atau ginjal tidak mengurangi beratnya reaksi akut pada iskemia-reperfusi yang menginduksi pankreatitis pada tikus. Iskemia dilakukan dengan cara mengklem arteri splenika inferior selama 30 menit dan diikuti reperfusi selama 6 jam, 12 jam, 1 hari, 2 hari dan 3 hari. Dari penelitiannya didapatkan adanya peningkatan vakuolisasi yang signifikan pada 24-48 jam setelah reperfusi. ${ }^{12}$

\section{SIMPULAN}

Pada kelompok yang tidak diberi perlakuan iskemia-reperfusi ginjal (kontrol) tidak ditemukan adanya perubahan gambaran histopatologi pankreas. Ditemukan perubahan gambaran histopatologi pankreas berupa edema ringan dan vakuolisasi ringan pada kelompok tikus yang diberi perlakuan iskemia 45 menit. Pada kelompok tikus yang diberi perlakuan iskemia 45 menit diikuti reperfusi 1 jam dengan gambaran histopatologi edema ringan, infiltrasi leukosit ringan dan vakuolisasi ringan. Sedangkan pada kelompok tikus yang diberi perlakuan iskemia 45 menit diikuti reperfusi 2 jam ditemukan selain edema ringan dan infiltrasi leukosit ringan, didapatkan vakuolisasi sedang. Pada kelompok yang diberi perlakuan iskemia 45 menit diikuti reperfusi 24 jam, ditemukan gambaran histopatologi berupa edema ringan, infiltrasi leukosit sedang dan vakuolisasi sedang.

\section{DAFTAR PUSTAKA}

1. Granger DN, Kvietys PR. Reperfusion injury and reactive oxygen species: The evolution of a concept. Redox Biology 6 (2015) 524-51.
2. Zarbock A, Eroglu A, Erturk E, Ince C, Westphal $M$. Ischemia-reperfusion injury and anesthesia. Biomed research international. 2014 Jun 19;2014.

3. Malek M, Nematbakhsh M. Renal ischemia/ reperfusion injury; from pathophysiology to treatment. J Ren Inj Prev. 2015;4(2):20.

4. Hussein AM, Abd-Elkhabir A, Abozahra A, Baiomy A, Ashamallah SA, Sheashaa HA, et.al. Pancreatic injury secondary to renal ischemia/ reperfusion (I/R) injury: Possible role of oxidative stress. Physiol Res. 63: 47-55. 2014.

5. Collard CD, Gelman S. Pathophysiology, clinical manifestasion, and prevention of ischemiareperfusion injury. Anesthesiology. 2001;94(6):1133-8.

6. Salvadori M, Rosso G, Bertoni E. Update on Ischemia-Reperfusion Injury in Kidney Transplantation: Pathogenesis and Treatment. World J Transplantation. 2015. 24;5(2): 52-67.

7. Kalogeris T, Baines CP, Krenz M, Korthuis RJ. Cell Biology of Ischemia/Reperfusion Injury. Int Rev Cell Biol. 2012; 298: 229-317.

8. Galindo MF, Jordan J, Garcia CG, Cena V. Reactive oxygen species induce swelling and cytochrome c release but not transmembrane depolarization in isolated rat brain mitochondria. British Journal of Pharmacology (2003) 139, 797 804.

9. Chrysikos DT, Sergentanis TN, Zagouri F, Psaltopaulou T, Theodoropoulos G, Flessas I, et.al. Lazaroid U-74389G administration in pancreatic ischemia-reperfusion injury: A swine model encompassing ischemic precondition. JOP. J Pancreas (Online). 2015; 16(2):176-84.

10. Warzecha Z, Dembinski A, Ceranowicz P, Dembinski M, Kownacki P, Konturek SJ, et.al. Immunohistochemical exprression of FGF-2, PDGF-A, VEGF dan TGFâ RII in the pancreas in the course of ischemia/reperfusion-induced acute pancreatitis. Journal of Physiology and Pharmacology. 2004, 55, 4, 791-810.

11. Amiralevi SH, Trianto HF, Novianry V, Zakiah M. Efek paparan formaldehid oral akut pada histologi hati tikus wistar jantan. Jurnal Cerebellum. 2017 ; 3 (3). 
Elva Rosiana, dkk, Gambaran Histopatologi Pankreas Tikus Putih

12. Warzecha Z, Dembinski A, Ceranowicz P, Cieszkowski J, Konturek SJ, Dembinski M, et.al. Ischemic preconditioning of the hindlimb or kidney does not attenuate the severity of acute ischemia/ reperfusion-induced pancreatitis in rats. Journal of Physiology and Pharmacology. 2008 ; 59 (2): $357-52$ 